\title{
Paulo e o discurso no areópago: desafios e superações do Cristianismo urbano. Um estudo de At 17,22-34
}

Paul's speech in the Areopagus: challenges and overcoming

of urban Christianity. A study of Acts 17,22-34

ISIDORO MAZZAROLOa

\section{Resumo}

O discurso de Paulo no Areópago de Atenas estabelece um paradigma muito claro no que concerne à prática evangelizadora e aos desafios dos cristãos nas primeiras décadas. Os pagãos estavam muito abertos a novidades religiosas; não só filósofos estoicos e epicureus, mas de outras correntes de pensamento sempre estavam atentos para novas teorias e realidades. Paulo aproveita o espírito de religiosidade dos pagãos para fazer a sua proposta de identificação do Deus desconhecido.

Palavras-chave: Religião. Enculturação. Valorização. Conhecimento.

\section{Abstract}

Paul's speech in the Areopagus of Athens establishes a very clear paradigm with regard to the evangelizing practice and to the challenges of Christians in the first decades. Pagans were very open to religious News; not only stoic philosophers and epicureans, but from other currents of thought, they were always on the lookout for new theories and realities. Paul takes advantage of the pagan spirit of religiosity to make his proposal to identify the unknown God.

Keywords: Religion. Enculturation. Valorization. Knowledge.

\footnotetext{
a Pontifícia Universidade Católica do Rio Grande do Sul (PUCRS), Porto Alegre, RS, Brasil. Doutor em Exegese Bíblica, e-mail: mazzarolo.isidoro@gmail.com
} 


\section{Introdução}

A proposta de Paulo: do politeísmo e da polilatria ao monoteísmo teocêntrico e cristocêntrico, um desafio multifacetário, pluridirecional e extremamente complexo. Ainda que parte do livro dos Atos dos Apóstolos possa conter arranjos do seu autor, é inegável a capacidade, a fortaleza de espírito e a tenacidade de Paulo. Ele estabelece um método pastoral inigualável, não só para os tempos antigos, mas ainda não verificável nos dias atuais. Paulo sabe caminhar, descobrir, preparar e instituir homens e mulheres como colaboradores nas metrópoles e vilas. $O$ método pastoral é eficiente e eficaz por causa da grande qualidade e preparação do mestre e de seus colaboradores.

Ainda que a autenticidade do discurso tenha sido colocada em xeque por diversos autores, os quais argumentam que não seria de Paulo, mas de um discípulo que fez um arrazoado sobre essa inscrição ao Deus desconhecido (VIKENHAUSER, 1981, p. 290), não existem razões para diminuir a importância da capacidade discursiva e persuasiva do Apóstolo.

Nossa proposta neste ensaio é realçar as tensões, os conflitos e as lições que emergem do fato de Paulo ter sido convidado a apresentar suas propostas à grande elite de Atenas. E, em termos hermenêuticos, ficaria uma pergunta: quem são os convidados a falar para os membros dos areópagos de hoje? Por que o discurso teológico parece estar distanciado de suas grandes plateias desejosas de conhecimento e de verdades?

\section{Paulo e as cidades}

Paulo não é um evangelizador da "roça", nem mesmo um beduíno do deserto; é o homem das três culturas, das três filosofias e da única religião: o cristianismo. Nas suas autodefinições, afirma: da raça de Israel e da tribo de Benjamim (Fl 3,5-7); perseguia a igreja e progredia no zelo das tradições paternas (Gl 1,13-14); hebreu, israelita, descendente de Abraão e ministro de Cristo (2Cor 11,21-33); nascido em Tarso, na Cilícia, mas criado e educado em Jerusalém, aos pés de Gamaliel (At 22,3-5). 
O local do nascimento, se Tarso (Cilícia) ou Gishala (Israel), ${ }^{1}$ ainda suscita debates; no entanto, demonstra que ele, desde criança, teve contatos fortes com a cultura helenística em Tarso. Seus pais não eram excessivamente ortodoxos, pois eles haviam comprado o passaporte de cidadania romana, do qual Paulo se serve algumas vezes (At 16,37; 22,25-26).

Paulo fala, inicialmente, aos que primeiro possuem o "conhecimento da palavra e o conhecimento da gnôsis" (PAGELS, 1992, p. 54). Dessa forma compreendemos por que ele se dirige sempre às sinagogas, em primeiro lugar, e, depois, aos cidadãos das metrópoles. Ele estava convencido de que os judeus possuíam a capacidade do entendimento em virtude da tradição e das Escrituras e, depois, aos pagãos. Em parte, Paulo segue o relato do envio dos Doze, segundo Mt 10,1-10: primeiro às ovelhas perdidas da casa de Israel. No entanto, a missão the mostrou que os pagãos eram mais acolhedores da Boa Nova.

Se adotarmos o Livro dos Atos como um "diário de bordo"2 vemos que nenhum outro evangelizador pode ser comparado ao Apóstolo dos gentios, considerando as circunstâncias, as condições e a época (cf. 2Cor 11,21-29). Paulo possuía, sem dúvida, conhecimentos profundos do helenismo, da língua grega, do ambiente político-religioso dos romanos e, de família e formação, do judaísmo.

Em todas as cidades do império romano, havia judeus e sinagogas, frutos da diáspora, ainda nos tempos do império persa. A língua comum era o latim, a língua da cultura era o grego e, nas sinagogas, era o hebraico. Paulo não visitava os campos e as periferias. Ele acreditava em um projeto de evangelização urbana, mesmo sabendo da complexidade de ritos, mitos e manipulações religiosas como em Éfeso (At 19,23-40).

\footnotetext{
1 MURPHY-O'CONNOR, J. Jesus e Paulo, vidas paralelas, p. 28-29. Nestas páginas, o autor discute a referência de Jerônimo, o qual afirma que Paulo nasceu na Gishala, sendo uma Vila da Galileia e não da Judeia. Esta informação de Jerônimo devia estar baseada em um comentário de Orígenes à carta de Filemon, comentário que, infelizmente, se perdeu. Em favor do testemunho de Jerônimo, no entanto, estava o conceito de Judeia, que significava toda a Palestina "dos judeus", sem fazer distinção entre Judeia, Samaria e Galileia.

${ }^{2} \mathrm{O}$ Livro dos Atos não é uma cronologia da missão dos primeiros cristãos e da missão de Paulo e seus companheiros, mas os eventos narrados não podem ser tratados como obra literária do autor.
} 
Paulo dependia da cidade para sobreviver, pois, segundo At 1-4, ele era fabricante de tendas e provia o seu sustento com as próprias mãos (At 20,3335). Quem usava as tendas eram os soldados romanos que viviam em acampamentos móveis, de acordo com as necessidades de deslocamentos em virtude dos conflitos.

Quando Paulo, retoricamente, enumera os lugares onde passou por perigos, divide o mundo em cidade, floresta selvagem e mar $(2$ Cor 11,26). Seu mundo não inclui a chora, a região produtiva; fora da cidade nada existe - eremia. O autor do Livro dos Atos dificilmente pode estar errado quando apresenta Paulo ousando dizer ao tribuno, admirado de que Paulo sabia grego, que ele é "cidadão de cidade não desprezível" (At 21,39), (MEEKS, 1992, p. 22).

Ao escrever aos Romanos, Paulo afirma que, naquelas regiões (entendendo-se a Ásia, a Macedônia e a Acaia, até a llíria) já haviam recebido o Evangelho, e seu projeto de longa data era chegar à metrópole imperial, mas não só chegar “aos confins do mundo”, isto é, à Espanha (Rm 15,22-33).

\section{Paulo e o conhecimento da religiosidade grega}

Atenas era uma metrópole cultural, política, econômica e religiosa. Ela estava repleta de estátuas de divindades, mas nela havia também uma sinagoga (At 17,16-17).

A religiosidade helenística era aberta: todos tinham sede de novidades e temas que provocassem diatribes, especialmente quando surgisse um orador convencido de sua superioridade como Paulo (cf. At 17,21). Em teoria, a influência da civilização grega sobre a religião cristã tem, em muitos campos sido reconhecida por estudiosos da literatura teológica; da mesma forma sobre o judaísmo tardio.

Sem uma evolução pós-clássica da cultura grega, o surgimento de uma religião cristã mundial teria sido impossível. É claro que esse processo de cristianização do mundo de fala grega dentro do Império Romano não foi de maneira alguma unilateral, pois, ao mesmo tempo, significou a helenização do cristianismo (JAEGER, 2014, p. 13).

Já na sua infância em Tarso (At 22,3-5), Paulo conhecia muitos mitos, ritos e práticas pagãs greco-romanas. Os atributos dos deuses, não raro, 
confundiam as suas especificidades. A mitologia (e as crenças na teocracia) vinculava a situação econômica dos povos diretamente à grandeza ou à pequenez de seus deuses protetores. Na época das dinastias egípcias, os cultos dos grandes faraós aos seus deuses ultrapassavam as fronteiras. Assim, a tentação tomou conta dos filhos de Samuel, quando estes, mesmo subornando os anciãos justos, querem que Samuel mude a forma de governo, como era em todas as outras nações (1Sam 8,5). Fazer como as outras nações significava submeter o povo aos regimes escravocratas dos seus líderes, acreditando que um rei forte era sinônimo de prosperidade; mas a realidade era outra e a ralação com Deus poderia ficar em segundo plano.

A surpresa de Paulo em Atenas não era pela presença de ídolos, mas pela quantidade ou excesso, talvez. Os gregos não inventaram todos os deuses, eles também eram herdeiros de esquemas anteriores egípcios e persas.

$\mathrm{Na}$ verdade, havia muita transmigração de ritos, símbolos e crenças. $\mathrm{Na}$ chamada metamorfose das divindades encontram-se muitas adaptações, mutações, ou mesmo, aceitações intactas de símbolos de outras culturas. 0 politeísmo, não obstante suas manifestações concretas de culto, pode não ser mais que uma metamorfose de uma monolatria egípcia do culto de uma mesma deusa, com tenta mostrar Apuleus (Metamorfose, IX, p. 226), (MAZZAROLO, 2011, p. 27).

Há uma só divindade sobre a terra, com diferentes ritos e uma forma variada de nomeações - os Frígios, que são uma raça primeva, chamam-me Pessinuntica, a mãe dos deuses; os aborígenes da Ática chamam-me Minerva; os de Chipre e outras ilhas de Páfia chamam-me Vênus; os de Creta e arredores, Diana Dictinna; nas três línguas da Sicília, Stygia Proserpina; os Heleusinianos, a antiga deusa Ceres. Muitos me chamam Júnia, outros Beluna, outros Hecata; os Etiópicos de Áres e os Egípcios, nas cerimônias religiosas, chamam-me pelo verdadeiro nome, a Rainha Ísis (MAZZAROLO, 2011, p. 28).

Paulo era um grande conhecedor da religiosidade helenística, especialmente no que tange ao confronto das igrejas paulinas e às associações religiosas ou às escolas filosóficas do seu tempo; além disso, nas cartas autênticas do Apóstolo, sem observar as discutidas ou os próprios discursos 
dos Atos, observa-se, com particular ênfase, o gênero da diatribe, fortemente helenístico (PENNA, 2009, 9.57).

"O grego era a língua urbana universal das províncias orientais, contudo não além dos muros da cidade" (MEEKS, 1992, p. 31). A importância cultural de Tarso (cidade natal?), de fato gozava de fama notável, como atesta o geógrafo Estrabão, que de Paulo foi, em parte, contemporâneo (aprox. 63 a. C. -21 d. C.).

Tanta paixão têm os homens (de Tarso) pela filosofia e por todas as outras formações enciclopédicas, a ponto de superar Atenas, Alexandria e qualquer outro lugar em que surgem escolas e diatribes filosóficas. Mas diferem destas porque todos os estudantes são do próprio lugar e os forasteiros não chegam facilmente. Todavia, os indigentes não permanecem na pátria, mas vão ao estrangeiro se aperfeiçoarem e depois se estabelecem de boa vontade lá, ao passo que somente poucos retornam à pátria (ESTRABÃO. Geogrf. 14.5.14., apud PENNA, 2009) ${ }^{3}$.

O investimento cultural de Tarso também valeu para Paulo, pois ele nunca se afastou do ambiente geocultural da língua grega. A vocação nasce, já, como uma missão entre os gentios (At 9,15), mas Paulo jamais abandonou seus irmãos de estirpe, pois queria que eles também encontrassem a verdadeira luz.

A transição da missão exclusiva aos judeus para uma missão aos Gentios não foi algo repentino, mas foi acontecendo aos poucos. Primeiro, ele voltou sua atenção para os de fala grega que eram os judeus helenistas, e depois, mais diretamente, aos pagãos. Os cristãos, devido à perseguição, tinham partido para os mais diferentes lugares e cidades. Uma das cidades mais importantes, nas primeiras décadas do cristianismo, foi Antioquia (da Síria) e para lá acorriam muitos grupos, além de judeus, também cipriotas cireneus de fala grega e muitos se convertiam, demonstrando que os helenizados estavam mais abertos à Boa Nova do Reino (At 11,19-21)(RIESNER, 1988, p. 110-111)

\footnotetext{
${ }^{3}$ Além disso, segundo Penna (2009), Estrabão acrescenta que Roma estava cheia de eruditos, provenientes de cidades gregas, como Tarso.

${ }^{4}$ Riesner (1988, p. 110-111) afirma que neste período a cidade ocupava o terceiro ou quarto lugar de importância dentro do império romano (Roma, Alexandria e Antioquia?) e, segundo Josefo (G. J. vii, 43), abrigava um número entre 150 e 600 mil habitantes, com uma comunidade de judeus que variava de 20 a 60 mil.
} 


\section{O discurso do Areópago:}

Os interlocutores de Paulo eram, sobremaneira, filósofos estoicos e epicureus (At 17,18).

1. Temas da discussão: a nova divindade — Jesus; a Ressurreição (At 17,18); a nova doutrina (At 17,19).

2. A surpresa de Paulo: a religiosidade e a quantidade de monumentos sagrados.

3. Uma observação especial: um altar a um deus desconhecido.

4. Uma proposta: a apresentação desse Deus desconhecido e da ressurreição.

Esse Deus não tem necessidades de coisa alguma (v. 25); é o criador, que de um só, fez uma multidão de filhos (v. 26); nós somos desta raça divina ( $v$. 29); os tempos de ontem eram da ignorância, mas hoje já está o julgamento, segundo a justiça (v. 31). Ao final do discurso, alguns da assembleia acreditam em Paulo, enquanto outros, saem rejeitando a proposta do desvelo do mistério divino (v. 32-33).

Alguns estudiosos argumentam que o Areópago era o tribunal da colina do deus Marte (deus da guerra, na mitologia romana). Sócrates fora condenado por ensinar novas doutrinas e existência de deuses estranhos. Paulo se apresenta na agorá e prega um novo Deus, aquele que os atenienses cultuavam sem conhecer. A questão é: Paulo foi convidado a falar aos filósofos estoicos e gnósticos? Ou, ele foi inquirido a justificar a nova doutrina sobre o Deus desconhecido e a ressurreição do corpo? Convite ou intimação? Enquanto Paulo pregava na praça pública, o povo que passava expressava reações diferentes. Alguns escutavam com interesse, outros saíam da roda da mesma forma que tinham entrado. Contudo, o tribunal do Areópago classificou Paulo como um spermalogos, que significa um catador de sementes, um conversador. Mas, em se tratando de uma nova religião e de um novo Deus, o Conselho dos Anciãos deveria fazer uma averiguação. Assim é difícil saber se foi um convite para expor a teoria do Deus desconhecido ou se foi uma investigação sobre a nova religião? 
Paulo aceita ir até o Areópago sinal de intrepidez, ousadia, coragem e conhecimento. Todos os deuses conhecidos estavam lá, menos UM. A esse Deus ele iria apresentar, colocando-se no meio deles. Nas diatribes da agorá, estavam filósofos e seus opositores: os estoicos e epicuristas. Em teologia, eles eram, essencialmente, panteístas (BRUCE, 1988, p. 330) ${ }^{5}$. O Areópago era o lugar do Conselho Supremo (hoje, Supremo Tribunal), que tinha atributos diversos, mas variava de acordo com os tempos. O lugar era dedicado a Ares (Marte - romano), filho de Zeus e Hera, na antiga religião grega.

A mitologia, a polilatria e o panteísmo eram a religiosidade corrente, antes do cristianismo. No Areópago se reunia esse Conselho que fazia a jurisprudência também em matéria de religião e moral (BRUCE, 1988, p. 331). Discernir a respeito do verdadeiro Deus era uma missão que se iniciava pelo Areópago. O conhecimento de Deus, conforme Rm 1,19-22, era acessível a todos pela criação, no entanto, a capacidade ou o desejo de aderir a esse Deus sofria o impacto da idolatria (BRUCE, 1988, p. 334).

Ao abrir seu discurso, Paulo usa uma linguagem conciliadora que associa surpresa, admiração e constatação: Cidadãos atenienses! Vejo-vos homens muito religiosos (At 17,22).

Alguns estudiosos interpretam o lexema deisidaimonestérous (At 17,22) como supersticiosos. No grego clássico, deisidaimônia tem uma relação com a religião, temor da divindade, religiosidade intensa e, por decorrência, pode significar superstição (STAUDINGER, 1980, p. 676), mas o sentido da palavra não se aplica ao contexto de Paulo no Areópago. A polilatria não é superstição. Os povos antigos eram politeístas, mas não se pode dizer que não houvesse monolatrias em meio a tanta diversidade religiosa. É neste aspecto que emerge a sabedoria de Paulo. Se ele acusasse os filósofos, os pensadores estoicos, epicuristas, plantonistas e gnósticos de supersticiosos, ele teria fracassado ainda na Agorá (praça central, local de comércio popular) de Atenas e, jamais teria sido convidado ao Areópago.

\footnotetext{
${ }^{5}$ A Agorá estava situada ao norte da Acrópolis e foi o primeiro lugar que Paulo visitou ao chegar em Atenas. Nela havia uma um pilar sobre o qual estava a cabeça de Hermes e, logo em seguida, uma floresta de ídolos (BRUCE, 1988, p. 330).
} 
Paulo respeita profundamente as culturas, a religiosidade, os costumes e outros elementos culturais das cidades por onde anda. Pode-se afirmar que ele faz uma hermenêutica perfeita da profecia messiânica de Isaías (42,2-4): ele não quebra a cana já rachada, nem apaga a mecha que ainda fumega, mas está prestes a se apagar; ele consertará a cana e reavivará a chama que está se extinguindo.

Paulo não parte do ideal, mas do real. Essa é a pedagogia messiânica da embaixada do Logos (Jo 1,14). Os atenienses não eram supersticiosos, mas muito religiosos, visto que, o verdadeiro Deus poderia ser totalmente desconhecido.

Paulo está de pé (statheis), no meio do seu auditório seleto de filósofos, epicuristas e estoicos (17,22), e se dirige aos seus ouvintes de forma categórica e respeitosa, em um vocativo majestático: Andres athênaioi (homens atenienses), uso clássico do vocativo (cf. At 1,14; 19,35), em todas as coisas, sob todos os aspectos, vos vejo muito religiosos. A expressão katá panta indica um olhar geral, nos mais diferentes ângulos, por isso, Paulo, depois de contemplar o pilar com o busto de Hermes e de todas as estátuas dos ídolos, considerou os atenienses muito religiosos. O adjetivo deisidaímôn tem um significado positivo, não obstante alguém possa ver como superstição. Na interpretação de At 17,22, o sentido deve ser considerado um elogio à religiosidade dos atenienses: Eu vos vejo como um povo muito, muito religioso (BAUER, 1971, p. 344). Soaria muito paradoxal que, com tanto conhecimento dos mitos gregos e das crendices, ele os tratasse como supersticiosos. Era importante partir do espírito de religiosidade existente para falar de outro Deus. O ponto de partida já existia: era esse devocionismo exagerado e distorcido. Sempre que um olhar diferente é posto sobre algo, o resultado da observação projeta uma compreensão diversa, mas isso não pode ser considerado um erro. Erro foram as formas de como o cristianismo considerou todas as outras religiões africanas, indígenas e de outros povos. Pode-se propor algo novo, mas é sempre bom partir do que já existe, mesmo de uma religiosidade "desvirtuada".

O modo de empostar, o discurso é semelhante ao utilizado na sinagoga da Antioquia da Pisídia (At 13,16-43), quando ele se dirige ao público com a chamada - Homens de Israel... - e depois faz o histórico de Jesus, passando 
pelas Escrituras. No Areópago, contudo, não invoca as Escrituras, mas a realidade dos deuses e, para cativar melhor a atenção, se debruça em torno do Deus desconhecido (LONGENECKER, 1981, p. 475).

\section{A estratégia da nova religião e a sede por novidades}

Paulo é um gigante no pensamento e na ação. Pode ser chamado de “teólogo"? Teólogo é aquele que sabe organizar um plano de doutrina bem sistematizado e, sob esse prisma, talvez não possa ser classificado como teólogo. Contudo, ele é um pastor que escreve aos fiéis das igrejas para orientar, confirmar, responder questões e refutar erros (BENOIT, 1988, p. 75).

Os povos pagãos não tinham dogmas religiosos; possuíam alguns códigos de ética convencionais, mas estavam sempre abertos às novidades. Diferentemente dos judeus que tinham uma religiosidade fechada, às custas de séculos de doutrinação, os pagãos amavam conhecer outras coisas. $\mathrm{Na}$ narrativa de João, enquanto os judeus queriam matar Jesus, por ver nele um herege e traidor dos costumes das tradições, os gregos, os quais tinham ido a Jerusalém para adorar o Deus dos judeus, dirigem-se a Filipe, dizendo: Queremos ver Jesus (Jo 12,21).

Paulo usa uma linguagem própria para entabular seus diálogos com os adoradores de deuses e com os amantes das novidades: o mistério. Assim ele começa dizendo que, (dierchómenos gár kai anatheôrôn) percorrendo e observando cuidadosamente os monumentos religiosos da cidade, encontrou um altar devotado ao Deus desconhecido (At 17,23). Paulo utiliza muitas vezes (6x 1Cor; $6 x \mathrm{Ef} ; 4 \mathrm{x} \mathrm{Cl}$; $2 x \mathrm{Rm}$ ), sempre no contexto de que aquilo que é desconhecido, misterioso e, por vezes, terrificante, agora foi revelado.

O discurso começa em tom de novidade, de respeito profundo à religiosidade dos pagãos e nisso está o grande mérito do conhecimento da cultura helenística. Por isso, não é possível admitir as interpretações de que Paulo trate os atenienses com desprezo ou ridicularizando a mitologia.

Muitos estudiosos acreditam que a arte retórica dos discursos de Paulo, especialmente no Livro dos Atos, seja, na verdade, um arranjo de Lucas, enquadrando as formas na perspectiva do seu público ouvinte (LONGENECKER, 1981, p. 476). Nessa perspectiva, parôxsúneto tó pneuma (At 
17,16) deve ser interpretado como uma provocação, uma comoção ou um impacto do espírito, mas não como um surgimento de raiva ou inflamação de agressividade.

Por que o Deus desconhecido era importante? Porque era ali que ele precisava começar a teoria da superioridade dele em relação aos filósofos estoicos e epicuristas. O Deus que eles não conheciam agora podiam conhecer. Paulo se serve de arquétipos helenísticos para atrair seus debatedores. Um dos elementos importantes era desvelar os mistérios celestes, os protótipos divinos e, para tal, utiliza com frequência a palavra mistério.

Os filósofos e espiritualistas de Atenas gostavam de palavras retumbantes como sabedoria, mistério, conhecimento e, diante disso estava o motivo da atração pela linguagem de Paulo. Como afirma Benoit, Paulo era dotado de uma grande inteligência e do conhecimento da revelação que recebera de Cristo e do Espírito, os quais se expressam de modo essencial na sua teologia (BENOIT, 1988, p. 75).

Ele afirma que não se colocava entre os gregos com palavras de sabedoria, pois estas ocasionariam apenas questões apologéticas e diatribes intelectuais; mas usou a simplicidade a humildade, linguagem suficiente para dar-lhes a conhecer os mistérios de Deus e de Jesus Cristo crucificado (1Cor 2,15). É na linguagem do Espírito e da humildade que ele ensinou a sabedoria de Deus, misteriosa e oculta, desde antes da criação do mundo e, que os príncipes deste mundo não chegaram a conhecer (1Cor 2,7-9). A palavra mistério ocorre 28 vezes (BW10) no NT, destas, 24 nos escritos de Paulo. Isso mostra como o Apóstolo se servia de uma linguagem provocativa para entabular diálogos e atrair a atenção dos seus ouvintes ou leitores. Seu esforço era incomensurável para persuadir os seguidores a acreditar que, em Jesus Cristo, todos os mistérios estavam revelados.

Ao percorrer as ruas de Atenas e contemplar a grandiosidade e a multiplicidade de altares, Paulo deve ter ficado espantado, no sentido de admiração, encantamento e surpresa, mas não no sentido de irritação, de raiva ou de algum sentimento de fúria, como alguns ousam interpretar. Ele sabe onde está pisando, por isso, não tem dúvidas de aproveitar qualquer espaço e oportunidade para fazer a proposta dele, do verdadeiro Deus. 


\section{O Deus desconhecido é o criador de todas as coisas; o Deus desconhecido x Zeus - apologia}

O altar ao Deus desconhecido era um ponto de partida muito importante para acentuar o interesse dos filósofos e sábios atenienses. O texto dos Atos dos Apóstolos, e também os comentadores, não esclarecem o suficiente, mas presume-se que, nesse altar, onde estava essa inscrição, não deveria ter qualquer estátua ou representação. Propor aos gnósticos a descoberta desse Deus, afirmando que era o único e verdadeiro, era uma forma bastante ousada. Sem pretender ofender, mas em outras palavras, estava afirmando que todo o conhecimento dos gnósticos não tinha conseguido desvendar a principal divindade.

Os gregos haviam importado todas as divindades e cultos às divindades dos povos conquistados, especialmente os cultos mistéricos das divindades persas. Havia uma quantidade enorme de altares aos deuses protetores. Sabemos que havia deuses para todas as situações, e não era novidade. Os povos antigos possuíam deuses para invocar em todas as circunstâncias, pois a teocracia era uma crença absoluta no poder das divindades.

Não é correto caracterizar os atenienses de idólatras ou de outros conceitos negativos, pois a religiosidade deles era aquela que haviam herdado dos seus antepassados. Atenas não representava uma grande cidade sob os aspectos econômicos e políticos, mas continuava como uma referência da cultura helenística e a pupila de toda a Grécia (VIKWNHAUSER, 1981, 287). Atenas era uma cidade cosmopolita, mas, segundo Flávio Josefo, uma das acusações contra Sócrates era de que ele introduzira divindades novas (daimónia) e, uma sacerdotisa, de nome Teóride, tinha sido incriminada e morta pelo mesmo motivo, pois era proibido ensinar, mesmo que em segredo, novos cultos a divindades estrangeiras (VIKWNHAUSER, 1981, p. 289).

No teor do discurso, Paulo não estaria introduzindo uma nova divindade, pois ela já existia, contudo, era desconhecida. Se, por um lado, o discurso demonstra uma apologese desse Deus com todos os outros deuses e certo desprezo pela religiosidade dos mitos, por outro, pode indicar que os atenienses adoravam esse Deus único e verdadeiro, mesmo sem saber e conhecer. 
Os gregos sabiam que os deuses não necessitavam de nada, mesmo assim, faziam oferendas e sacrifícios em sua honra. Da mesma forma, os profetas condenavam a hipocrisia e a falsidade dos sacrifícios, oferendas e festas sem a justiça (Am 4,4-6; 5,21-27; Os 8,13; Is 1,11). Os deuses eram perfeitos e não tinham necessidade de serviços dos homens. Os atenienses, depois de edificar altares a todos os deuses conhecidos, acreditavam que poderia haver outro Deus, desconhecido. Assim, para não entristecer esse Deus, deixaram um espaço de "boas vindas".

Paulo aproveita exatamente essa brecha e afirma que Ele é o verdadeiro e único. A passagem da multiplicidade para a unicidade divina não seria tão simples e não seria resolvida numa exposição retórica com argumentos teológicos e filosóficos. A coletânea de deuses que eles possuíam significava, por um lado, a abertura para o mundo, por outro, a crença na necessidade da ligação com a transcendência. O dualismo gnóstico favorecia essa dupla percepção da vida e do mundo.

\section{Somos da raça divina $(17,28 b)^{6}$}

A participação na divindade poderia dar-se através dos sacrifícios idolátricos, da prestação de subserviência e de outras formas de culto. Paulo tinha clareza de que a participação nos ritos e sacrifícios geravam comunhão com os ídolos, da mesma forma que a participação na eucaristia gerava a comunhão com Cristo (1Cor 10,14-22).

A insistência na participação com a divindade (At 17,29) tem um tom apologético, pois os gregos acreditavam na separação e no distanciamento dos deuses. E, este Deus verdadeiro é maior que todos os deuses, inclusive do

\footnotetext{
6 "O texto completo do qual é tirado o versículo dos Atos 17,28b diz - Comecemos por Zeus. Não devemos nós homens esquecer de nomeá-lo; de Zeus estão plenas todas as estradas, todas as praças dos homens, pleno dele está o mar e os portos. Em cada coisa temos necessidade de Zeus, nós todos - porque dele somos a mesma estirpe (EUSÉBIO DE CESAREIA, Preparação Evangélica, XIII, 12,3; PG XXI, 1101, refere um fragmento de Aristóbulo, filósofo judeu-helenista, fr. 4, no qual se cita Arato, Fenômenos, 1,9; cf. também CLEMENTE DE ALEXANDRIA, Strom., 119; PG VIII, 808). Além do prólogo do tratado astronômico de ARATO, Fenômenos, do parentesco ou geração divina dos homens se fala também no hino de Cleanto a Zeus (século III a. C.) e nos discursos de Dion de Prusa, XII, 27; XXX, 26)." (FABRIS, 1991, p. 334, nota 31).
} 
grande Zeus. As teses do discurso estão sobre pilares sólidos para afirmar que esse Deus desconhecido era o criador de todas as coisas e de tudo. O combate à idolatria já era uma orientação veterotestamentária (Dt 5,18; Is 44,9-20; Sab 13,5.15), mas Paulo não ataca de frente a mitologia e, aproveitando o “Devocionismo exagerado", afirma que havia espaço para outro Deus, do qual somos reflexo imperfeito e inacabado (2Cor 3,18). Zeus, Afrodite, Hermes e outras grandes divindades representadas nas estátuas estavam longe e não podiam ajudar os seres humanos; por isso, o Deus criador de todo o cosmos é um Pai que conhece as necessidades dos seus filhos (MAZZAROLO, 2014a, p. 227).

Paulo afirma que o ser humano é da estirpe divina pela criação, não pela representação de imagens. As obras de arte são expressões dos artistas, mas nenhum artista retrata a divindade como ela é. O ouro, a prata e as pedras preciosas utilizadas pelos artistas caracterizavam a beleza e a importância atribuída à obra de arte, mas eram sempre estátuas inanimadas (WILLIANS, 1996, p. 339).

A afirmação de que em Deus "vivemos, nos movemos e existimos” (At $17,28)$ aponta para três realidades — vida, movimento, ser — temas que não se encontram em nenhuma outra passagem bíblica (VIKENHAUSER, 1981, p. 304).

$\mathrm{Na}$ referencialidade do Apóstolo, o ser humano participa da Transcendência já na criação, pois o Deus único e criador criou filhas e filhos à sua imagem e semelhança (Gn 1,26-27). As imagens inanimadas não poderiam ser expressões do Deus Verdadeiro (MARSHALL, 1983, p. 289). O discurso sobre a ineficiência das imagens prepara o passo seguinte da apresentação de Deus que cria e restaura, em Jesus Cristo, através da encarnação e ressurreição (LONGENECKER, 1981, p. 477).

Apologeticamente, Paulo se serve de um poema grego, atribuído a Epimênides, de Creta, para melhor persuadir os atenienses:

Eles construíram uma tumba para ti, ó santo e alto;

Os cretenses, sempre mentirosos, bestas malvadas, barrigas ociosas; ${ }^{7}$

\footnotetext{
${ }^{7}$ Os cretenses se outorgavam o orgulho de serem os protótipos dos gregos e, em Creta, teriam nascido todas as divindades. O túmulo de Zeus também estava na Ilha. Zeus era pai 
Mas não estás morto!

Tu vives e habitas para sempre, pois em ti

Vivemos, nos movemos e existimos! ${ }^{8}$.

Zeus não era apenas um deus, entre outros, mas o deus supremo para os gregos, especialmente para os filósofos estoicos. É nesse contexto que Paulo se apropria de conceitos helenísticos para apresentar o Deus, que é Pai de nosso Senhor Jesus Cristo (Gl 3,26), (BRUCE, 1988, p. 340).

\section{Os tempos da ignorância 17,30}

A ignorância pode ter um grau de inocência, mas nem sempre é escusável da culpabilidade. No discurso de Jesus, diante do ódio gratuito e sem motivo, afirmou: Se eu não tivesse vindo e não Ihes tivesse falado, não seriam culpados, mas agora eles não têm desculpa do seu pecado (Jo 15,22). ${ }^{9}$

O kêrygma cristão fala da ignorância dos homens e promete lhes dar um conhecimento melhor e, como as filosofias, ele se refere a um mestre e professor que possui e revelou a verdade (JAEGER, 2014, p. 18). Paulo, ao dirigir-se aos intelectuais do Areópago, utiliza argumentos conhecidos dos filósofos estoicos e epicuristas: "Porque somos também de sua linhagem", seus argumentos são amplamente estoicos e calculados para persuadir uma mente filosófica culta (JAEGER, 2014, p. 20).

Nos discursos proféticos, a idolatria pode ser considerada um tempo de ignorância. O povo de Israel, resgatado por Deus da escravidão, esqueceu a ação libertadora de Yahweh, que não necessita de nada; ao contrário, age com braço forte e poderoso em favor do povo, mas o povo se deixa seduzir pelos ídolos (Is 46,1; Jr 10,5). Esse Deus não habita em tempos construídos pelas

das virtudes e, em seu epitáfio constava: Aqui jaz Picus, homem que também foi chamado Zeus. A carta a Tito também descreve os cretenses com conceitos negativos: Um dos próprios profetas deles, disse deles: os cretenses são sempre mentirosos, animais ferozes, ventres preguiçosos $($ Tt 1,12) (MAZZAROLO, 2014b, p. 261).

8 BRUCE, 1988, p. 339. Em nota, Bruce explica que a datação deste poema é discutida, contudo, este verso é utilizado por Theodoro de Mopsuéstia 9350-428), reproduzindo Diógenes (história de Laércio, p. 336, n. 62), para ilustrar a inscrição: Ao Deus desconhecido.

9 Diversos textos bíblicos ilustram a ignorância como atenuante, mas não isentam da responsabilidade total, pois há sempre um dano, um dolo que necessita de reparação (LV 4,2.13.22.27; Nm 15,24-29; Ef 4,18; 1Pd 1,14; 2,15). 
mãos humanas (At 17,24), mas é criador do universo e autor da vida. Portanto, não é Zeus, mas Yahweh que é a fonte da vida (MARSHALL, 1983, p. 287).

O culto aos ídolos foi, desde sempre, no cristianismo, considerado uma ignorância e subserviência a entidades que não ajudam e não estão próximas dos humanos. Os ídolos exigem sacrifícios de diferentes naturezas, inclusive de seres humanos e isso se comprova pela arqueologia de muitos povos antigos. Não só no Oriente antigo, mas nas Américas, especialmente no México e no Peru (Incas, Maias e outras tribos), os dados arqueológicos comprovam a prática de sacrifícios humanos aos deuses, ainda que isso não se constituísse em questão ordinária, sendo, porém, sempre um ato cruel do medo dos deuses.

Ao entrar em Atenas, ficou encantado; não raivoso, violento, etc., como muitos interpretam o lexema deisidaimonestérous (At 17,22). Os politeístas eram muito religiosos, supersticiosos, temerosos em relação aos desígnios dos deuses. Assim eram todos os povos antigos, e sabemos que o monoteísmo bíblico não caiu pronto e nem foi implantado pelo Decálogo como um decreto dogmático. A metáfora dos quarenta anos no deserto indica que para mudar um esquema mental é necessário, no mínimo, o percurso de uma vida.

A ignorância não imputa culpabilidade jurídica, mas, a partir do conhecimento, implica responsabilidade (Jo 15,22). Assim, a proposta do Deus desconhecido significava uma apologese à idolatria de forma suave, pastoral e delicada. Paulo sabia em que terreno estava pisando, contudo não estava imune a reações contrárias. Paulo usa uma linguagem própria para quem se dirige a pagãos, partindo da filosofia helenística que buscava o conhecimento dos deuses (MARSHALL, 1983, p. 288).

Caminhando pelas ruas e avenidas de Atenas, Paulo observava os nichos, altares e representações de deuses e semideuses, mas ele não via nessas coisas objetos de beleza artística, mas sinais de uma idolatria alucinada (WILLIAMS, 1996, p. 332). Estaria, aqui, Paulo caracterizando os atenienses como ignorantes sob o aspecto da idolatria? Fabris afirma que, na tradição bíblica sapiencial, haviam sido estigmatizadas as aberrações idolátricas como ignorância (Sb 13,1; 14,22; SI 79,6; Jr 10,25), (FABRIS, 1991, 334). Paulo, no entanto, usa argumentos jurídicos e a responsabilidade recai, de modo implacável, aos que possuem o conhecimento (cf. $\mathrm{Rm}$ 2,17-3,8). Para o 
cristianismo primitivo, os pagãos estavam na ignorância por não possuírem um conhecimento real do Deus verdadeiro (1Ts 4,5; Ef 4,18; 1Pd 1,14). Desta forma, partindo da tese de que os atenienses adoravam um Deus desconhecido (At 17,4), a proposta do conhecimento do verdadeiro Deus tornava-se um imperativo. E não só o verdadeiro Deus, mas também ao homem (Jesus) que Ele enviou, a fim de justificar o arrependimento e a ressurreição dos mortos (At 17,30-31).

\section{Paulo e os desafios no mundo urbano}

Por que Paulo é chamado de homem de três culturas, três cabeças e, pelos opositores, "o fundador do cristianismo"? Por que ele é acusado de ser o fundador do cristianismo? Quais razões levaram o Apóstolo dos gentios a ser o protótipo de evangelização urbana? Quais foram as experiências sentidas no caminho da evangelização (2Cor 11,1-33)? Quantas prisões, castigos e processos ele enfrentou? Onde estava a força da resistência? O que levou Paulo a ter tanto receio de tornar inútil a cruz de Cristo (1Cor 1,17)? Que tipo de tensão pode surgir entre batizar e evangelizar? Onde começou a certeza do Cristo ressuscitado que lhe deu forças para lutar contra as feras em Éfeso (1Cor 15,32)? Muitas perguntas poderiam ser anexadas nessa investigação, contudo parecem suficientes para a proposição de uma pergunta atual: Por que, hoje, 2021, os evangelizadores perderam muito a influência nas cidades?

E, se evangelizar não é uma questão de status, honra, orgulho (1Cor $9,16)$, então, para evangelizar é preciso ter capacitações, possuir a arte da comunicação, saber e conhecer o terreno debaixo dos pés.

Os conhecimentos de Paulo conseguiram reunir a nata da elite, isto é, mestres, filósofos, gnósticos e outros. A novidade a ser apresentada era de interesse de muitos, mas eles também tinham seus argumentos, suas convicções e determinações. O discurso provocou uma reação controversa, visto que muitos acabaram por desprezar as argumentações, como se Paulo fosse um "charlatão" (VIKWNHAUSER, 1981, p. 288).

Na missiva aos romanos, Paulo está preocupado com a instrução, o conhecimento, formação intelectual e a solidez espiritual (Rm 10,14-17). 
O discurso no Areópago produziu três reações: a. Os epicuristas consideraram o discurso absurdo e incompreensível, pois o dualismo os impedia de crer na ressurreição; b. Os estoicos, de modo mais delicado, dizem que iriam escutá-lo outra vez; c. Alguns adeptos se tornam discípulos, como Dâmaris e Dionísio.

Os desafios da missão nos são bem retratados por Lucas, em todo o livro do Atos. Aqui, de qualquer forma, temos um exemplo das dificuldades encontradas pelo cristianismo primitivo, mas também uma amostra das convicções e da audácia dos evangelizadores.

As grandes cidades exigiam capacidades de diálogo, conhecimentos e muita flexibilidade. No caso específico do discurso, Paulo utiliza todos os argumentos possíveis do quadro helenístico, mas não se atém aos mitos e sim ao Deus verdadeiro. Um diálogo com elites filosóficas e políticas exigia preparação e conhecimento. Um diálogo com os judaizantes conservadores era outro passo importante. O esforço de unir os opostos: de um lado os excessivamente livres, enquanto não tinham regras morais, culturais e religiosas e do outro, os excessivamente fechados em suas tradições patriarcais e preconceituosas. Quer judeus, quer pagãos estavam nas metas evangelizadoras do Apóstolo (1Cor 1,24).

O cristianismo primitivo superou muitas barreiras e obstáculos para sair de sua base judaica e inserir-se nos mais diferentes contextos do mundo antigo. Infelizmente, o conhecimento que possuímos do cristianismo primitivo se limita, em grande parte, às bordas do mar Mediterrâneo, e toda a expansão pelo Oriente e África ficou em textos e testemunhos tardios. Contudo, não restam dúvidas que o cristianismo nasceu e se alicerçou nas metrópoles.

A presença das mulheres na missão gerava conflitos com discípulos de origem judaica (1Cor 9,1-5). Ainda que tenha sido certo tempo mais tarde, vemos a pressão dos judaizantes sobre as comunidades evangelizadas por Paulo, inserindo glosas em suas cartas (1Cor 11,2-16; 14,33b-36), na tentativa de harmonizar as igrejas helenizadas com as da Palestina (MAZZAROLO, 2011, p. 195). Nas igrejas de maioria helenista, as mulheres assumiam papéis importantes e fundamentais no funcionamento de todas as atividades das comunidades. Em Filipos, a anfitriã é Lídia (At 16,15), uma empresária comerciante de púrpura, da cidade de Tiatira; e, dentro das comunidades da 
cidade, aparecem outras duas protagonistas, que poderíamos chamar de conflitos domésticos, que são Síntique e Evódia (Fl 4,2). Na fundação da igreja de Éfeso, destaca-se a grande colaboradora Priscila, juntamente com seu esposo Áquila (At 18,19). As mulheres citadas em Rm 16,1-16 servem de espelho para investigar a pedagogia inclusiva de Paulo; mas ele não inventa a inclusão, a recebeu do próprio Cristo, juntamente com seu evangelho.

O protagonismo das mulheres, em muitas comunidades, era razão para conflitos e tensões. Muitas delas haviam se convertido ao cristianismo sem o consentimento dos seus maridos (1Cor 7,13). "Algumas mulheres exerciam funções carismáticas como oração e profecia na assembleia (1Cor 11,2-16); outras eram colaboradoras de Paulo como evangelistas e mestras" (MEEKS, 1992, p. 115).

\section{Conclusões}

Aprender com Paulo, o Areopagita (ROGERS, 2002, p. 21), é ser audacioso, corajoso e destemido. Não há obstáculo intransponível, pois se Deus é por nós, quem será contra nós? (Rm 8,31b). Por isso, ao aceitar o convite dos estoicos e epicureus, acompanhado de muitos curiosos e de outros convidados, colocou-se de pé, no meio do Areópago (Colina de Ares ou de Marte), junto ao altar do Deus desconhecido (At 17,22a). Nessa colina, situada a noroeste da Acrópole, em Atenas, era o lugar onde se reunia o Conselho até o século IV d. C. Durante o século VII a. C., o Conselho devia cuidar das leis da cidade; em 462/461, o Areópago deixou de ser o guardião das leis, mas conservou o poder de ouvir casos de homicídios, de lesões corporais e de outros casos de conflitos.

Durante o período do Império Romano, as funções do Conselho foram ampliadas, e Paulo foi levado para lá por filósofos estoicos e epicuristas interessados em saber mais sobre Jesus, sua religião e a ressurreição (At 17,1621), (MAZZAROLO, 2014a, p. 74).

O discurso do Areópago projeta pistas sempre atuais de diálogo, flexibilidade e espera. Paulo não esperava converter todos os filósofos, mas alguns acolheram a mensagem e, partindo destes, nasceu a igreja de Atenas. 
Paulo não escolhia as cidades e, por onde passava, não deixava de provocar, convocar, visitar e escrever (MAZZAROLO, 2011, p. 14-15). Era o seu método pastoral que deveria ser um manual, hoje, para os pastoralistas e anunciadores do Evangelho. O grande legado de Paulo, válido para nossos dias, envolve interpretar as suas utopias, isto é, levar o evangelho até o fim do mundo, na época era a Espanha ( $R m$ 15,24), mas começando próximo ou em casa, como ele mesmo fez, partindo da Antioquia para o mundo.

\section{Referências}

BAUER, W. Wörterbuch zum Neuen Testament. Berlin/New York: Walter de Gruyter, 1971.

BENOIT, P. Genese et évolution de la pensée paulinienne. In: LORENZI, L. (org.). Paul de Tarse, Apôtre de notre temps. Rome: Abaye de S. Paul, 1979.

BRUCE, F. F. The Book of the Acts. Revised Edition. Grand Rapids/Michigan: W. B. Ederdmans Publishing Company, 1988.

FABRIS, R. Os Atos dos Apóstolos. São Paulo: Loyola, 1991.

JAEGER, W. Cristianismo Primitivo e Paideia Grega. Santo André: Academia Cristã, 2014.

LONGENECKER, R. N. Acts. In: TENNEY, M. C.; LONGENECKER, R. N. John and Acts. [Expositor's Bible Commentary, with the New International Version]. Grand Rapids/Michigan: Zondervan, 1981.

MARSHALL, I. H. The Acts of the Apostles: An Introduction and Commentary. Grand Rapids, Michigan: William B. Eerdmans Publishing Company, 1983.

MAZZAROLO, I. O apóstolo Paulo, o Grego, o Judeu e o Cristão. Rio de Janeiro: Mazzarolo Editor, 2. ed, 2011.

MAZZAROLO, I. Atos dos Apóstolos ou Evangelho do Espírito Santo. Rio de Janeiro: Mazzarolo Editor, 2014a.

MAZZAROLO, I. Primeira e segunda carta a Timóteo e Tito. Rio de Janeiro: Mazzarolo Editor, 2014b.

MEEKS, W. A. Os primeiros cristãos urbanos: o mundo social do apóstolo Paulo. São Paulo: Paulinas, 1992.

MURPHY-O'CONNOR, J. Jesus e Paulo, vidas paralelas. São Paulo: Paulinas, 2008.

PAGELS, E. The Gnostic Paul; Gnostic exegesis of the Pauline Letters. Pensylvania: Trinity Press International, 1992. 
PENNA, R. Paulo de Tarso e os componentes gregos do seu pensamento. Atualidade Teológica, v. 31, p. 55-91, 2009.

RIESNER, R. Paul's Early Period: Chronology, Mission Strategy, Theology. Grand Rapids/Michigan: Willian B. Eerdmans Publishing Company, 1998.

ROGERS, G. Areópago. In: METZGER BRUCE, M.; COOGAN, M. D. (orgs.). Dicionário da Bíblia.v. 1. Rio de Janeiro: Jorge Zahar Editor, 2002.

STAUDINGER, F. "deisidaimónia”. In: BALZ, H.; SCHNEIDER, G. Exegetisches Wörterbuch zum Neuen Testament, Band I. Stuttugart/Berlin: W. Kohlhammer GmbH, 1980. p. 675-678.

VIKENHAUSER, A. Los Hechos de los Apóstoles. Barcelona: Herder, 1981.

WILLIAMS, D. J. Atos. [Novo comentário bíblico contemporâneo]. São Paulo: Editora Vida, 1996. 